\title{
Enhancing Students' Creativity through STEM Project-Based Learning
}

\author{
Sofi Hanif ${ }^{*}$, Agus Fany Chandra Wijaya², Nanang Winarno ${ }^{1}$ \\ ${ }^{1}$ International Program on Science Education, Faculty of Mathematics and Science Education, Universitas Pendidikan Indonesia, \\ Indonesia \\ ${ }^{2}$ Department of Physics Education, Faculty of Mathematics and Science Education, Universitas Pendidikan Indonesia, Indonesia \\ *Corresponding Author. hanifsofi@gmail.com
}

\begin{abstract}
In some school, teacher-centered is commonly found in the learning process. The learning process itself is still in the form of direct transfer of knowledge from teacher to students. Actually, students will learn better if they are engaged in a meaningful learning activity. STEM project-based learning is one of the alternative teaching strategies that engaged students in meaningful learning. The aim of this study is to investigate the impact of STEM project-based learning on students' creativity in the topics of light and optics. The study used qualitative research with the narrative design. Data collection technique that used is observation. The population is eight grade students in one of Junior Secondary School that is located in Bandung, Indonesia. The sample consists of 25 students that chosen based on purposive sampling technique. The data is obtained through Creativity Product Analysis Matrix (CPAM). There are three creativity dimensions that used in this study which are resolution, elaboration and novelty dimension. Students' creativity is obtained as much $76 \%$ which categorized as good. Based on the result, STEM project-based learning give a good impact on students' creativity. STEM project-based learning can be used as alternative teaching strategies in Junior Secondary School.
\end{abstract}

Keywords STEM Project-based learning, Students' creativity, Light and optics

\section{INTRODUCTION}

The advance of technology can produce competition in several life aspects, especially in education. The competition makes some countries change their education system and strategies that involving technology in the learning process. The use of technology in the learning process can be seen in the utilization of technology in making students' project. Students are more excited when making a project that involves the technology by constructing the power point which includes the byte, video clips, picture, text, and animation in the slide. Students identified that working with technology is easier and possible for students to work quickly and efficiently (Heafner, 2004).

Regarding that technology is important in this modern era, the education system should prepare students with the skills that need in facing the advance of technology. The students' skills in Indonesia do not really satisfy the skills needed in facing the advance of technology if the learning process only based on teacher-centered. In some school, teacher-centered is commonly found in the learning process. The learning process itself is still in the form of direct transfer of knowledge from teacher to students.
Students will learn better if they are engaged in meaningful learning activity (Fortus et al., 2005).

Science, Technology, Engineering and Mathematics (STEM) education has potential to improves the quality of education. STEM education integrates the contents and skills with science, technology, engineering, and mathematics. Therefore, Asmuniv (2015) stated that STEM education can improve the quality of human resource with interdisciplinary in preparing students career. STEM gives an opportunity for students to understand real-world problems based on those interdisciplinary subjects (Dugger, 2010). Interdisciplinary STEM aims to emphasize the importance of 21-century skill development such as adaptation skill, social skill, communication skill, problem-solving skill, and self-development (Bybee, 2010).

Science (S) explains the existence of objects and events, the laws and principle of these objects and events, and the relationship between them (Capraro, Capraro, \& Morgan, 2013). Technology is an innovation and modification of natural environment to produces things that needed and

Received: 5 October 2018

Revised: 26 December 2018

Published: 11 January 2019 
desired by a human (Dugger, 2010). Technology (T) maybe e-books, or online encyclopaedia which gives students direct access to find any information or sources; probes, sensors and experiments sets that enable students to collect data; social networking or websites that enables students access or contact the experts via online communication tools; presentation or video editing software that facilitate students in making presentation; and recording or analysis software that enables students to extend their capabilities (Bruce \& Levin, 1997). Engineering (E) is research and development based on science in order to manufacture certain products to solve problems (Capraro, Capraro, \& Morgan, 2013). Engineering in STEM project-based learning can be called the design process. Mathematics (M) defined as an abstract representational system used in the study of numbers, shape, structure and change, and the relationship between these concepts (Capraro, Capraro, \& Morgan, 2013).

Several studies have been observed about the STEM field in some cases. Previous studies have been measured pre-service science teachers interest in STEM career by interest survey (Winarno, Widodo, Rusdiana, Rochintaniawati, \& Afifah, 2017); the attitude of preservice science teacher regarding STEM area (Winarno et al., 2018); students' problem-solving skill and students' creativity based on girls' interest in STEM subject field (Cooper \& Heaverlo, 2013); students' STEM literacy by conducting STEM learning using Arduino-Android Game (Yasin, Prima, \& Sholihin, 2018); and students' science process skills, students' science concept and students' science content knowledge for gifted elementary students in the involvement of STEM (Robinson, Dailey, Hughes, \& Cotabish, 2014).

STEM project-based learning is one of learning model that can be used to satisfy the needs of STEM education and prepare students in facing the advance of technology. STEM project-based learning is the project-based model that integrate Science, Technology, Engineering and Mathematics (STEM) in curriculum design (Lou, Tsai, \& Tseng, 2011). The design process and interdisciplinary of instruction make STEM project-based learning is unique. The design process of STEM project-based learning starts with preparing well-defined outcome by setting the objective and planning the summative assessment of the project. Then, students will be given the ill-defined task that expresses their ideas to solve a complex problem with a different solution (Capraro, Capraro, \& Morgan, 2013).

Based on the study of Lou, Chou, Shih, \& Chung (2017), there are 5 stages of STEM project-based learning that can be adopted for the teacher. The stage of preparation is guiding students to understand the theme, scope, and problem. The stage of implementation required students to produce a project according to their design drawings and conducted the actual test. The stage of presentation is requiring students to present the project result. The stage of evaluation required the teacher to gives the evaluation or suggestion regarding students' project. The stage of correction was encouraged students to make the correction according to the evaluation.

Creativity is one of 21 st-century skill that needed by students in facing the advance of technology and preparing their future career. Based on teacher interview, there still many teachers who measure the cognitive aspects. From this case, there is an indication that students have a lack of skills, especially in creativity. Teachers have not trained students to strengthen their creativity. Even though, the curriculum that was developed is more emphasized in the creativity aspect. Creativity is one of important skill that should be fostered by students (Dawes \& Wegerif, 2004). Creativity refers to the creation of a novel and appropriate response, product, or solution to an open-ended task (Amabile, 2012). If the creativity relates to the learning and technology it will produce a high quality of work. In the recent study show that technology allows the students to construct several media that can help them to produce high quality of work in the creativity context (Loveless, 2002). STEM project-based learning has a chance to give a positive impact in creativity because students will develop their own idea to create the product.

Various studies have been proved that STEM projectbased learning gives effects in several aspects. STEM project-based learning has been measured students' creativity in aspects of adventurousness, curiosity, imagination and challenge (Lou, Chou, Shih, \& Chung, 2017); Students' learning attitude through multi-function electric vehicle (Tseng, Chang, Lou, \& Chen, 2013); Students' science achievement through the implementation of latent growth modelling (Erdogan \& Capraro, 2016); Students' imagination and STEM knowledge development for female high school students (Lou, Tsai, Tseng, \& Shih, 2014); Academic achievement for high, middle, and low achievers (Han, Capraro, \& Capraro, 2014); and perception of pre-service and in-service teachers regarding the implementation of STEM project-based learning in science class (Siew, Amir, \& Chong, 2015).

Students creativity through STEM project-based learning has been conducted in the previous study. The previous study investigated four dimensions of creativity in aspects of adventurousness, curiosity, imagination and challenge in the concept of density, buoyancy, fluid, heat transfer and thermal energy (Lou, Chou, Shih, \& Chung, 2017). For further identification, this study will investigate students creativity with another three dimensions of creativity. The three dimensions of creativity that used are resolution, elaboration, and novelty, while the concept that was chosen is light and optics. Therefore, the aims of this study are to investigate the effect of STEM project-based learning on students' creativity in the concept of light and optics. 
Table 1 Population and sample

\begin{tabular}{lllll}
\hline Population & Sample & $\mathbf{N}$ & $\begin{array}{l}\text { Percentage } \\
\mathbf{( \% )}\end{array}$ & $\begin{array}{l}\text { Total } \\
(\mathbf{\%})\end{array}$ \\
\hline $\begin{array}{l}8^{\text {th }} \text { Grade } \\
\text { Students }\end{array}$ & Male & 13 & 52 & 100 \\
& Female & 12 & 48 & \\
\hline
\end{tabular}

\section{METHOD}

\subsection{Research Method}

The study used qualitative research with the narrative design. Narrative research designs are one of the qualitative procedures where researcher describes the things that happened during class, then collects and explains stories about students' lives and experience in the form of narratives (Creswell, 2012). Data collection technique that used is observation. In collecting data, the researcher has a role as non-participant in the study. In non-participant observation study, the researcher only watches and observe the activities in the class and not directly involves in the observed situation.

\subsection{Population and Sample}

This study is conducted in one of Junior Secondary School that is located in Bandung, Indonesia. Kurikulum
2013 is implemented as the curriculum in this school. The population of this study is 8th-grade students between 14 until 16 years old. About 25 students that consist of 13 males and 12 females are selected as sample. The sampling technique that used was purposive sampling which requires the researcher to uses a personal judgment and believes to choose the samples (Fraenkel, Wallen, \& Hyun, 2012). 8thgrade students in this school are categorized as the high, medium and low achievement. Thus, researcher considered sample who have the medium achievement. The sample and population are represented in Table 1.

\subsection{Research Instrument}

The research instrument was used to collect the data needed in this study. Research instrument that used is creativity product analysis matrix (CPAM) that was developed by Besemer and Treffinger (1981). The data that was collected from students' creativity is based on a creative product that was made by students during STEM project-based learning activity. The students' creativity is scored by 1 until 3 scales for each criterion of creativity. The criterion that used is valuable, useful, well-crafted, expressive, original and novelty. The creativity product analysis matrix (CPAM) can be shown in Table 2.

Table 2 Instrument for creative product analysis matrix (CPAM)

\begin{tabular}{|c|c|c|c|c|}
\hline \multirow{2}{*}{$\begin{array}{l}\text { Creative } \\
\text { Dimension }\end{array}$} & \multirow{2}{*}{ Criterion } & \multicolumn{3}{|c|}{ Score } \\
\hline & & 1 & 2 & 3 \\
\hline Novelty & Germinal & $\begin{array}{l}\text { The lower level of germinal: } \\
\text { The product is inspiring } \\
\text { others with the creation }\end{array}$ & $\begin{array}{l}\text { Medium level of germinal: } \\
\text { The product is inspiring others to } \\
\text { try something new }\end{array}$ & $\begin{array}{l}\text { High level of germinal: } \\
\text { The product is inspiring others } \\
\text { to try something new by } \\
\text { directly give ideas to develop } \\
\text { more product design }\end{array}$ \\
\hline Resolution & Valuable & $\begin{array}{l}\text { The lower level of Valuable: } \\
\text { The product is not } \\
\text { compatible with the purpose } \\
\text { and not relates to the } \\
\text { concept }\end{array}$ & $\begin{array}{l}\text { Medium level of Valuable: } \\
\text { The product is compatible with } \\
\text { the purpose and not relates to the } \\
\text { concept }\end{array}$ & $\begin{array}{l}\text { High level of Valuable: } \\
\text { The product is compatible with } \\
\text { the purpose and relates to the } \\
\text { concept }\end{array}$ \\
\hline \multirow[t]{2}{*}{ Elaboration } & $\begin{array}{l}\text { Well } \\
\text { Crafted }\end{array}$ & $\begin{array}{l}\text { The lower level of Well } \\
\text { Crafted: } \\
\text { The product is done well }\end{array}$ & $\begin{array}{l}\text { Medium level of Well Crafted: } \\
\text { The product is done well with the } \\
\text { good looking design }\end{array}$ & $\begin{array}{l}\text { High level of Well Crafted: } \\
\text { Students take an effort to give } \\
\text { interesting product design by } \\
\text { using some materials }\end{array}$ \\
\hline & Expressive & $\begin{array}{l}\text { The lower level of expressive: } \\
\text { The product is presented } \\
\text { with lacking body language } \\
\text { and need to control speaking } \\
\text { tone, not understandable }\end{array}$ & $\begin{array}{l}\text { Medium level of expressive: } \\
\text { The product is presented with } \\
\text { lacking body language and need } \\
\text { control speaking tone, but } \\
\text { understandable }\end{array}$ & $\begin{array}{l}\text { High level of expressive: } \\
\text { The product is presented in a } \\
\text { communicative way (using } \\
\text { effective body language and } \\
\text { clear voice) and understandable } \\
\text { manner }\end{array}$ \\
\hline
\end{tabular}


Table 3 The activities of STEM project-based learning for each stage

\begin{tabular}{|c|c|c|}
\hline Meeting & Stage & Activity \\
\hline \multirow[t]{4}{*}{$1^{\text {st }}$} & Preparation & Students recognize the project theme and scope \\
\hline & & Students find the information from the internet regarding the basic concept in making project \\
\hline & & Students discuss tools and materials that will be used \\
\hline & & Students produce design drawing \\
\hline \multirow[t]{2}{*}{$2^{\text {nd }}$} & Implementation & Students make the project based on the design drawing \\
\hline & & Students conduct an actual test of their product \\
\hline \multirow[t]{3}{*}{$3^{\text {rd }}$} & Presentation & Each group present their product and basic concept behind the product \\
\hline & Evaluation & Teacher gives an evaluation regarding students' product \\
\hline & & Students conduct peer evaluation regarding another groups' product \\
\hline $4^{\text {th }}$ & Correction & Students make self-correction about the product according to suggestion and feedback \\
\hline
\end{tabular}

\subsection{Research Procedure}

The stages used in this study consist of preparation, implementation, presentation, evaluation, and correction (Lou, Chou, Shih, \& Chung, 2017). This study needs fourth meeting to finish all stages of STEM project-based learning, i.e. (1) First meeting, researcher conducted preparation stage which leads students to understand the theme and scope, (3) Second meeting, researcher conducted implementation stage which let students to create the product based on their design drawing, (4) Third meeting, researcher conducted presentation and evaluation stage that give opportunities for other to give suggestion regarding the project that are presented, and (5) Fourth meeting, researcher conducted correction stage which give students opportunity to improve their product. The learning activities of each stage STEM Project-based learning can be represented in Table 3 .

\section{RESULT AND DISCUSSION}

The implementation of STEM project-based learning is related to the integration of Science (S), Technology (T), Engineering (E), and Mathematics (M). In this study, students will make the mini projector based on the STEM field. The integration of STEM in making mini projector activities can be presented in Table 4 .

Science $(\mathrm{S})$ field in this study discusses the concept of the image that was formed in the lens. Before making the mini projector, students should recognize how is the image formation in both of convex lens and concave lens. If

Table 4 The integration of STEM in making the mini projector

\begin{tabular}{|c|c|c|c|}
\hline $\begin{array}{l}\text { Science } \\
\text { (S) }\end{array}$ & $\begin{array}{l}\text { Technology } \\
\text { (T) }\end{array}$ & $\begin{array}{l}\text { Engineering } \\
\text { (E) }\end{array}$ & $\begin{array}{l}\text { Mathematics } \\
\text { (M) }\end{array}$ \\
\hline \multirow{9}{*}{$\begin{array}{l}\text { The } \\
\text { formation } \\
\text { of Image } \\
\text { in Lens }\end{array}$} & Find & Design & Magnification \\
\hline & Information & Drawing & Calculation \\
\hline & from the & & \\
\hline & Internet & & \\
\hline & Decide the & & \\
\hline & tools and & & \\
\hline & materials & & \\
\hline & Conduct an & & \\
\hline & Actual Test & & \\
\hline
\end{tabular}

students already understand about the characteristic of the image, they are able to decide the proper lens that used in constructing the mini projector. In this concept, students were expected to determine the correct length or room of lens, so the mini projector will produce a real and enlarged image. Technology ( $\mathrm{T}$ ) field in this study can be sawed in preparation stage when students used the internet to find any information that was needed in making a mini projector. Furthermore, students should make their decision to select the suitable tools and materials. Technology ( $\mathrm{T}$ ) field also can be found in the implementation stage when students conducted the actual test, this activity requires students to check whether their mini projector is worked or not. Engineering (E) in this study can be observed in the preparation stage when students made their own design drawing. Design drawing that was made by students should be suitable with the concept of image formation in the lens. In order to make students easier to construct the mini projector, students were expected to put detail information in their design drawing, such as focal length, type of lens and distance of the object. Mathematics (M) in this study refers to the magnification of image that was produced by the mini projector. Students apply the formula to calculate the magnification of a mini projector.

The result shows the qualitative data that was obtained based on creativity rubric. Students' creativity measured based on students' product which is making a simple projector. The students' creativity is assessed by using the Creative Product Analysis Matrix (CPAM) that adapted from Besemer and Treffinger (1981). CPAM is grouped into three creative dimensions which are resolution, elaboration, and novelty. The data is obtained based on the criterion of each creativity dimension. Each criterion is scored with a rubric scale from 1 until 3 based on several requirements.

Creativity is the creation of a novel and appropriate response, product, or solution to an open-ended task (Amabile, 2012). Two criteria have been selected for each three dimensions of creativity based on Besemer and Treffinger (1981). Useful and Valuable criteria have been selected for the resolution dimension. Valuable Criteria 
Table 5 Creative product analysis matrix (CPAM) rubric

\begin{tabular}{|c|c|c|c|c|c|c|c|c|c|c|c|c|c|c|c|c|}
\hline \multirow{2}{*}{ Creative Product Criteria } & \multirow{2}{*}{ Criterion } & \multicolumn{3}{|c|}{ Group 1} & \multicolumn{3}{|c|}{ Group 2} & \multicolumn{3}{|c|}{ Group 3} & \multicolumn{3}{|c|}{ Group 4} & \multicolumn{3}{|c|}{ Group 5} \\
\hline & & 1 & 2 & 3 & 1 & 2 & 3 & 1 & 2 & 3 & 1 & 2 & 3 & 1 & 2 & 3 \\
\hline \multirow{2}{*}{ Novelty } & Germinal & & $\sqrt{ }$ & & $\sqrt{ }$ & & & & & $\sqrt{ }$ & & $\sqrt{ }$ & & $\sqrt{ }$ & & \\
\hline & Original & & $\sqrt{ }$ & & $\sqrt{ }$ & & & & & $\sqrt{ }$ & & $\sqrt{ }$ & & & $\sqrt{ }$ & \\
\hline \multirow{2}{*}{ Resolution } & Valuable & & & $\sqrt{ }$ & $\sqrt{ }$ & & & & & $\sqrt{ }$ & & & $\sqrt{ }$ & & $\sqrt{ }$ & \\
\hline & Useful & & $\sqrt{ }$ & & & $\sqrt{ }$ & & & & $\sqrt{ }$ & & $\sqrt{ }$ & & & $\sqrt{ }$ & \\
\hline
\end{tabular}

Table 6 Students' creativity result

\begin{tabular}{|c|c|c|c|c|}
\hline \multicolumn{3}{|c|}{ Creativity Dimension } & \multirow{2}{*}{$\begin{array}{l}\text { Ave- } \\
\text { rage }\end{array}$} & \multirow{2}{*}{$\begin{array}{l}\text { Cate- } \\
\text { gory }\end{array}$} \\
\hline Resolution & Elaboration & Novelty & & \\
\hline $77 \%$ & $87 \%$ & $63 \%$ & $76 \%$ & Good \\
\hline
\end{tabular}

refers to how the product is judged worthy by others because the product fills the financial, physical, social, and psychological needs by the judgment, while Useful Criteria refers to how the product has clear and meet the practical application. Then, Well-crafted and Expressive criteria have been selected for elaboration dimension. Well-crafted Criteria refers to how the product appears and has been worked or reworked with care which idea developed, while Expressive Criteria defined as how should the product is presented with the communicative way and understandable manner. For the last, Germinal and Original Criteria was chosen for novelty dimension. Germinal Criteria defined as the product is likely to suggest an additional for the future creative product, while Original Criteria is how the product is unusual and rare to find with the same product idea in a similar experience.

The result is obtained based on the criterion of each creativity dimension. Each criterion is scored with a rubric scale from 1 until 3 based on several requirements. The creative rubric of CPAM is presented in Table 5.

All criteria of each creativity dimension are used to assess a student's project product after implementing

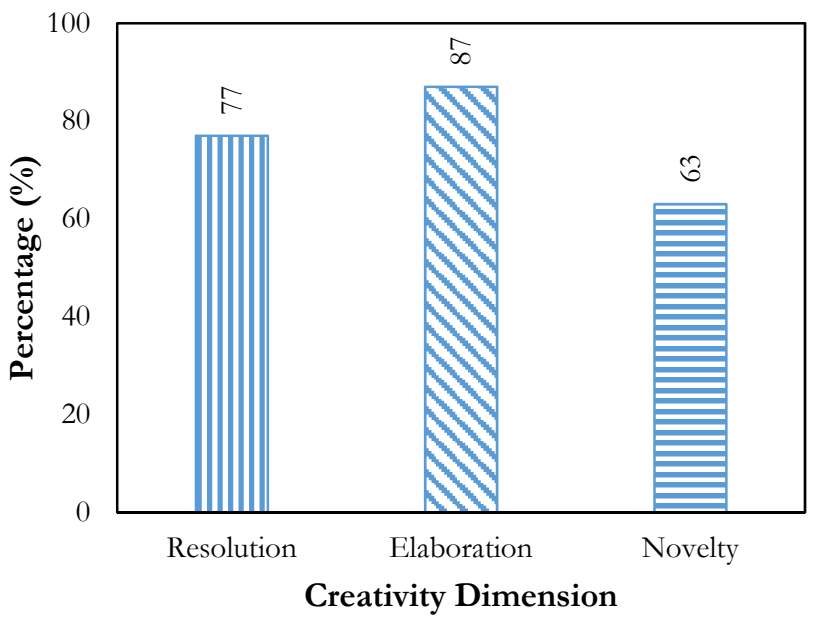

Figure 1 Students creativity for each dimension
STEM project-based learning. The recapitulation of students' creativity in this study can be seen in Table 6 .

The result is shown that each creativity dimension has different attainment. resolution dimension obtained $77 \%$, elaboration dimension obtained $87 \%$ and novelty dimension obtained $63 \%$. The comparison of students' creativity result for each dimension can be seen clearly in Figure 1.

The average score of each dimension creativity after implementing STEM project-based learning is obtained $76 \%$ which categorized as good based on Purwanto (2009). Based on the result of this study, students who learn light and optics through STEM project-based learning has good creativity. Students are trained to realize their ideas by designing and constructing the product in STEM projectbased learning. Thereby, students were given the opportunity to develop their idea by using several tools and materials that can improve the quality of the product. It can be inferred that students' who learned science by using STEM project-based learning have good creativity. The result is in line with the study that is conducted by Lou, Chou, Shih, \& Chung (2017) who stated that the implementation of STEM project-based learning gives the positives influence on the effective development of creativity. The result of this study also in line with the previous finding which stated that STEM approach, especially in hands-on activity through project-based learning, requires students to think critically and creatively (Siew, Amir, \& Chong, 2015).

In the preparation stages, students are freely given an opportunity to investigate the problems and find some information that needed to solve the problems from the internet. This is appropriate with Munandar (2004) who stated that creativity can be developed in a free situation to conduct an investigation. Preparation stages also give an opportunity for students to discuss with their group in determining the project based on information that is obtained from the internet. The discussion is used to stimulate students in delivering their idea. It is in line with Rustaman, et. al. (2003) who stated that discussion gives several advantages to stimulates students' courage and creativity in expressing their idea, students also have responsibilities for the result of group discussion. 


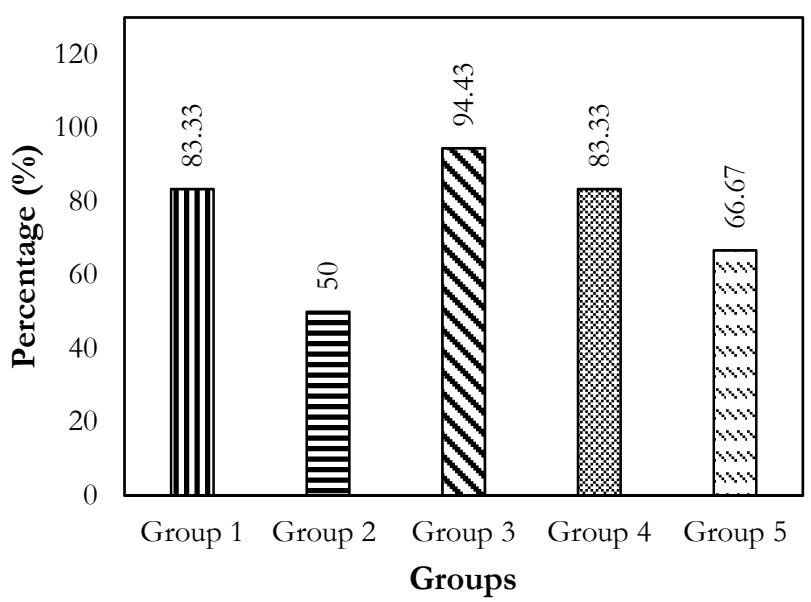

Figure 2 Students' creativity result for each group

In implementation stages, students conduct an experiment to create the product that has been designed. Furthermore, students conduct an actual test to make sure that their product is working. Munandar (1999) stated that creative thinking skill can be developed through experiment and discussion activity between students.

In presentation stages, students try to communicate their product and also their design. Students express some obstacles that they are faced in making the project. As it is known that expressive is one criterion of elaboration dimension. Students should think creatively, how to draw attention when present the product. Expressive criteria refer to the product is presented with the communicative way and understandable manner (Besemer \& Treffinger, 1981).

In the evaluation and correction stages, students made a repairment to improve their product. These stages become a reflection for students to find how is the best way to improve the quality of the product. One of effective teaching should give students opportunities for reflecting their own thinking, receiving feedback from other students, and revising the ones' thinking as a result of new information freely. Capraro, Capraro, \& Morgan, (2013) stated that the effective instruction should provide the opportunities for students in evaluating scientific evidence based on their own understanding, connecting the theory with their own explanation, and participating active learning. In this case, students' creativity plays a role in creating an effective solution to repair students' product.

When conducted STEM project-based learning, the class is divided into five groups that consist of five students to create the project. All group members should cooperate with each other in making a simple projector. The recapitulation of students' creativity for each group is presented in Table 7.

Based on the result in Table 7, there are different achievements of creativity for each group. Group 1 obtained $83.33 \%$, group 2 obtained $50 \%$, group 3 obtained $94.43 \%$, group 4 obtained $83.33 \%$, and group 5 obtained
Table 7 Students creativity result for each group

\begin{tabular}{lllll}
\hline \multirow{2}{*}{$\begin{array}{l}\text { Gro- } \\
\text { up }\end{array}$} & \multicolumn{2}{l}{ Creativity Dimension } & \\
\cline { 2 - 4 } Resolution & Elaboration & Novelty & \\
\hline 1 & $83.33 \%$ & $100 \%$ & $66.67 \%$ & $83.33 \%$ \\
2 & $50 \%$ & $66.67 \%$ & $33.33 \%$ & $50 \%$ \\
3 & $100 \%$ & $83.3 \%$ & $100 \%$ & $94.43 \%$ \\
4 & $83.33 \%$ & $100 \%$ & $66.67 \%$ & $83.33 \%$ \\
5 & $66.67 \%$ & $83.33 \%$ & $50 \%$ & $66.67 \%$ \\
\hline
\end{tabular}

$66.67 \%$. Based on the result, there is a distant gap in creativity result between group 2 with another group, because group 2 has the lowest percentage of creativity. The comparison of students' creativity results for each group can be shown in Figure 2.

The distant gap can be found between group 3 and group 2. Group 3 has the highest percentage of creativity which obtained as much $83 \%$ categorized very good. Meanwhile, group 2 has the lowest percentage of creativity which obtained as much $50 \%$ categorized as very lack creativity. Group 2 also has the lowest percentage of three creativity dimension if compared with other groups.

When making the creative product, the class is divided into groups. Thus, each group worked and discussed together to developed their idea in making the creative product. Based on the result, each group has different attainment of creativity. However, there is a distant gap in creativity result between group 3 which categorized as very good and group 2 which categorized as very lack. The condition happened because group 2 always bicker among member when making the product. They blame each other if there is a member who is negligent with responsibilities. As the result, group 2 not take an effort to improve the quality of the product, while other groups attempted to improve their product quality. The students' product after implementing STEM project-based learning can be shown in Figure 3.

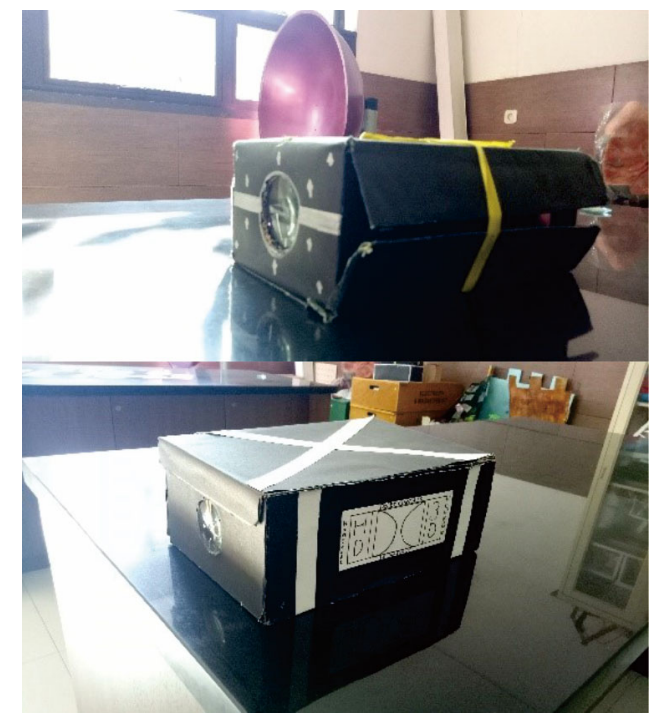

Figure 3 Students' product in making a simple projector 


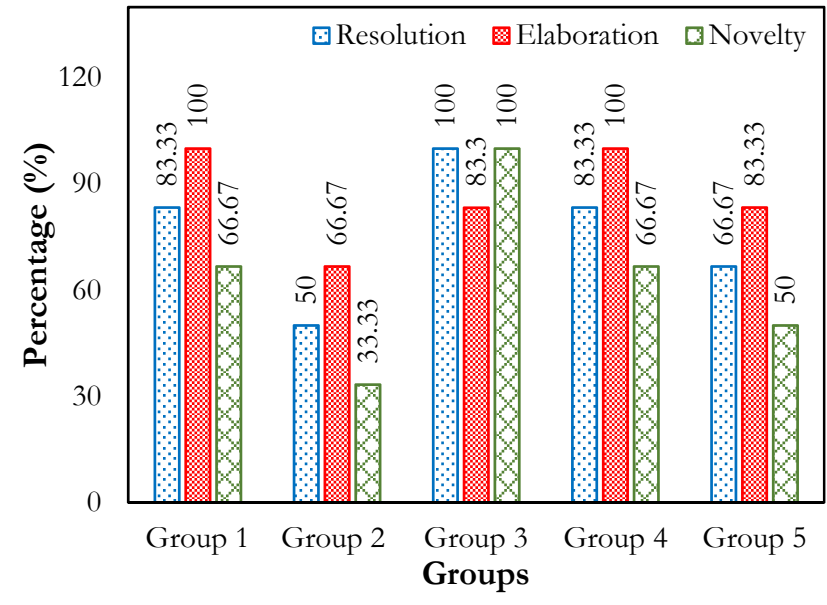

Figure 4 Creativity dimension for each group

Three creativity dimension of all groups have a different percentage. Group 2 has the lowest percentage of three creativity dimension compared with other groups. To make the comparison of each dimension creativity between all groups can be seen clearly, the result also changes into graphical form. The creativity result for each dimension creativity can be shown in Figure 4.

\section{CONCLUSION}

The students who implemented STEM project-based learning in the concept of light and optics have good creativity in the dimension of resolution, elaboration, and novelty. The creativity result that obtained as much as $76 \%$ which is categorized as good. STEM project-based learning can be used as alternative teaching strategies in Junior Secondary School.

\section{ACKNOWLEDGMENT}

Authors acknowledge principal of the school who already allowed to conduct the research about STEM project-based learning.

\section{REFERENCES}

Amabile, T. M. (2012). Componential Theory of Creativity. Harvard Business School, 1-10.

Asmuniv. (2015). Pendekatan Terpadu Pendidikan STEM Upaya Mempersiapkan Sumber Daya Manusia Indonesia yang Memiliki Pengetahuan Interdisipliner dalam Menyongsong Kebutuhan Bidang Karir Pekerjaan Masyarakat Ekonomi Asean (MEA). Retrieved October 23, 2017, from http://www.vedcmalang.com/pppptkboemlg/index.php/menuut ama/listrik-electro/1507-asv9

Besemer, S. P., \& Treffinger, D. (1981). Analysis of Creative Products: Review and Synthesis. The Journal of Creative Behavior, 15(3), 158178.

Bruce, B. C., \& Levin, J. A. (1997). Educational Technology: Media for Inquiry, Communication, Construction, and Expression. Journal of Educational Computing Research, 17(1), 79-102.

Bybee, R. W. (2010). Advancing STEM Education: A 2020 Vision. Technology and Engineering Teacher, 13(6), 30-35.

Capraro, R. M., Capraro, M. M., \& Morgan, J. (2013). STEM Project-Based Learning: An Integrated Science Technology Engineering and Mathematics (STEM) Approach. Rotterdam: Sense Publishers.
Cooper, R., \& Heaverlo, C. (2013). Problem Solving And Creativity And Design: What Influence Do They Have On Girls ' Interest In STEM Subject Areas? American Journal of Engineering Education, 4(1), 27-38.

Dawes, L., \& Wegerif, R. (2004). Thinking and learning with ICT: Raising achievement in primary classrooms. London: Routledge Falmer.

Dugger, W. E. (2010). Evolution of STEM in the United States. In 6th Biennial International Conference on Technology Education Research in Australia. Retrieved from http://www. iteea. org/Resources/PressRoom/AustraliaPaper. pdf.

Erdogan, N., \& Capraro, R. M. (2016). Viewing How STEM ProjectBased Learning Influences Students' Science Achievement Through the Implementation Lens: A Latent Growth Modeling. EURASLA Journal of Mathematics, Science \& Technology Education, 12(8), 2139-2154.

Fortus, D., Krajcik, J., Dershimer, R. C., Marx, R. W., \& MamlokNaaman, R. (2005). Design-based science and real-world problemsolving. International Journal of Science Education, 27(7), 855-879.

Fraenkel, J. R., Wallen, N. E., \& Hyun, H. H. (2012). How to Design and Evaluate Research in Education (Vol. 53). New York: McGraw-Hill. https://doi.org/10.1017/CBO9781107415324.004

Han, S. Y., Capraro, R. M., \& Capraro, M. M. (2014). How Science, Technology, Engineering, and Mathematics (STEM) Project-Based Learning (PbL) Affects High, Middle, and Low Achievers Differently: The Impact of Student Factors on Achievement. International Journal of Science and Mathematics Education, 13(5), 10891113.

Heafner, T. (2004). Using Technology to Motivate Students to Learn Social Studies. Retrieved July 3, 2018, from http://www.citejournal.org/volume-4/issue-1-04/socialstudies/using-technology-to-motivate-students-to-learn-socialstudies.

Lou, S.-J., Tsai, H.-Y., Tseng, K.-H., \& Shih, R.-C. (2014). Effects of Implementing STEM-I Project-Based Learning Activities for Female High School Students. International Journal of Distance Education Technologies, 12(1), 52-73.

Lou, S. J., Chou, Y. C., Shih, R. C., \& Chung, C. C. (2017). A Study of Creativity in CaC2 Steamship-Derived STEM Project-Based Learning. EURASLA Journal of Mathematics, Science \& Technology Education, 13(6), 2387-2404.

Lou, S. J., Tsai, H. Y., \& Tseng, K. H. (2011). STEM Online ProjectBased Collaborative Learning for Female High School Students. Kaohsiung Normal University Journal, 30, 41-61.

Loveless, A. M. (2002). Literature Review in Creativity. England.

Munandar, U. S. C. (1999). Mengembangkan Bakat dan Kreativitas Anak Sekolah. Jakarta: Gramedia Widiasarana Indonesia.

Munandar, U. S. C. (2004). Pengembangan Kreativitas pada Anak Berbakat. Jakarta: Rineka Cipta.

Purwanto, M. N. (2009). Prinsip-prinsip dan Teknik Evaluasi Pengajaran. Bandung: Remaja Rosdakarya.

Robinson, A., Dailey, D., Hughes, G., \& Cotabish, A. (2014). The Effects of a Science- Focused STEM Intervention on Gifted Elementary Students' Science Knowledge and Skills. Journal of Advanced Academics, 25(3), 189-213.

Rustaman, N. Y., Dirdjosoemarto, S., Yudianto, S. A., Achmad, Y., Subekti, R., Rochintaniawati, D., \& Nurjani, M. (2003). Strategi Belajar Mengajar Biologi. Bandung: JICA IMSTP FPMIPA UPI.

Siew, N. M., Amir, N., \& Chong, C. L. (2015). The Perceptions of Preservice and In-service Teachers Regarding a Project-Based STEM Approach to Teaching Science. SpringerPlus, 4(1), 1-20.

Tseng, K. H., Chang, C. C., Lou, S. J., \& Chen, W. P. (2013). Attitudes towards science, technology, engineering and mathematics (STEM) in a project-based learning $(\mathrm{Pj} \mathrm{BL})$ environment. International Journal of Technology and Design Education, 23(1), 87-102.

Winarno, N., Widodo, A., Rusdiana, D., Rochintaniawati, D., \& Afifah, R. M. A. (2017). Profile of Pre-Service Science Teachers Based on 
STEM Career Interest Survey. Journal of Physics: Conference Series, 895(1) 012170

Winarno, N., Widodo, A., Rusdiana, D., Rochintaniawati, D., Afifah, R. M. A., \& Putra, M. (2018). Investigation of Pre-Service Science Teachers' Attitudes Towards Science, Technology, Engineering and Mathematics (STEM). Advanced Science Letters, 24(4), 28192822.

Yasin, A. I., Prima, E. C., \& Sholihin, H. (2018). Learning Electricity using Arduino-Android based Game to Improve STEM Learning Electricity using Arduino-Android based Game to Improve STEM Literacy. Journal of Science Learning, 1(3), 77-94. 